\title{
MIF loss impairs Myc-induced lymphomagenesis
}

\author{
F Talos ${ }^{1}$, P Mena ${ }^{1}$, G Fingerle-Rowson ${ }^{2}$, U Moll ${ }^{1}$ and \\ 0 Petrenko*,1 \\ 1 Department of Pathology, State University of New York at Stony Brook, Stony \\ Brook, NY 11794, USA \\ 2 University Hospital Cologne, Medical Clinic I, Hematology and Oncology, \\ Joseph-Stelzmann-Str. 9, 50924 Cologne, Germany \\ * Corresponding author: O Petrenko, Department of Pathology, State University \\ of New York at Stony Brook, Stony Brook BST L9, NT, 11794, USA; \\ Tel: + 1631444 3520; Fax: + 1631444 3424; \\ E-mail: apetrenko@notes.cc.sunysb.edu
}

Received 20.12.04; revised 10.3.05; accepted 23.3.05; published online 10.6.05 Edited by RA Knight

\section{Abstract}

Macrophage migration inhibitory factor (MIF) is a potent regulator of inflammation and cell growth. Using the $\mathrm{E} \mu$-Myc lymphoma mouse model, we demonstrate that loss of MIF markedly delays the onset of B-cell lymphoma development in vivo. The molecular basis for this MIF-loss-induced phenotype is the perturbed DNA-binding activity of E2F factors and the concomitantly enhanced tumor suppressor activity of the p53 pathway. Accordingly, premalignant MIF-null E $\mu$-Myc Bcells are predisposed to delayed S-phase progression and increased apoptosis. MIF-deficient lymphomas that do arise under these conditions contain frequent ARF deletions and p53 inactivating mutations. Conversely, MIF expression is retained in tumors developed by wild-type $\mathrm{E} \mu$-Myc animals, and the presence of one or both MIF alleles is sufficient to accelerate the development of Myc-induced lymphomas. Collectively, these results indicate that MIF promotes Mycmediated tumorigenesis, at least in the B-lymphoid compartment, and implicate MIF as a mediator of malignant cell growth in vivo.

Cell Death and Differentiation (2005) 12, 1319-1328.

doi:10.1038/sj.cdd.4401653; published online 10 June 2005

Keywords: inflammation; p53; ARF; E2F1; DNA replication

\section{Introduction}

Over the past years, macrophage migration inhibitory factor (MIF) has been recognized as a potent regulator of inflammation and cell growth. ${ }^{1-4}$ MIF was originally identified as a product of activated T cells. ${ }^{5}$ However, subsequent work showed that MIF is almost ubiquitously expressed in various tissues, including neural, epithelial, and hematopoietic lineage cells. ${ }^{6-9}$ Studies using neutralizing antibodies implicated MIF in the development of pathologies of acute and chronic inflammation such as allograft rejection, wound repair, glomerulonephritis, inflammatory arthritis, and septic shock. ${ }^{10,11}$ Moreover, based on the observed correlation of MIF expression levels and clinical aggressiveness of tumors, ${ }^{12-16}$ it was suggested that MIF could serve as a connection between inflammation and cancer. ${ }^{17,18}$ However, the process by which MIF exerts its effect on target cells is not understood.

MIF is unique among cytokines in terms of its constitutive expression by a broad spectrum of cell types and its storage within the cytoplasm. ${ }^{11}$ Intracellularly, MIF complexes with the Jab1/CSN5 subunit of the COP9 signalosome, ${ }^{19}$ which regulates numerous signaling pathways involved in gene expression and cell cycle control. ${ }^{20-22}$ Several studies have indicated that activation of cell proliferation by MIF is due to a functional inactivation of the p53 tumor suppressor. ${ }^{17,18,23}$ Thus, MIF overexpression extends the lifespan of primary cells in vitro, inhibits Myc-induced p53-dependent apoptosis, and protects macrophages from NO-induced apoptosis. ${ }^{17}$ Conversely, when MIF is lost, cell survival and functions are compromised in a p53-dependent manner. ${ }^{17,18}$ It has been proposed that this functional suppression of p53 by MIF is based on interference with p53-dependent transcriptional activity. ${ }^{17,18}$ Accordingly, upregulation of MIF at sites of chronic inflammation might impair p53-dependent cellular responses towards DNA damage, and thus promote the accumulation of oncogenic mutations. ${ }^{17}$

We previously showed that primary fibroblasts derived from MIF-deficient mice exhibit E2F- and p53-dependent growth defects and reduced susceptibility to oncogenic transformation. $^{23-25}$ Concurrent deletion of the p53 gene reversed the observed phenotype of cells deficient in MIF, providing the first genetic evidence for a functional link between MIF and the p53 tumor suppressor. ${ }^{23}$ Here, we provide direct evidence for the tumor-promoting role of MIF in vivo. Using the $\mathrm{E} \mu$-Myc lymphoma mouse model, we demonstrate that loss of MIF delays the onset of B-cell lymphoma development. The molecular basis for this MIF-loss-induced phenotype is the perturbed activity of E2F transcription factors and the concomitantly enhanced antiproliferative response of the ARF-p53 pathway.

\section{Results}

\section{Loss of MIF impairs Myc-induced lymphomagenesis}

Recent studies have implicated the proinflammatory macrophage migration inhibitory factor (MIF) in interfering with the activity of the p53 tumor suppressor. ${ }^{17,18,23}$ Thus, MIF overexpression extends the lifespan of primary fibroblasts in vitro, inhibits Myc-induced p53-dependent apoptosis, and protects macrophages from NO-induced p53-mediated apoptosis. ${ }^{17}$ Conversely, when MIF is lost, cell survival and functions are compromised in a p53-dependent manner. ${ }^{18,23}$ Since the ARF-p53 axis is the dominant tumor suppression pathway in murine fibroblasts and lymphoid cells, ${ }^{30,31}$ we assessed the in vivo role of MIF in Myc-induced tumorigenesis. For this purpose, we used the well-characterized $\mathrm{E} \mu$-Myc transgenic mice, a model of human Burkitt's lymphoma. ${ }^{26,27}$ If MIF interfered with the mechanism of $\mathrm{p} 53$ activation in vivo, 
then deletion of the MIF gene should enhance the antiproliferative p53 response and thereby delay lymphomagenesis in $\mathrm{E} \mu$-Myc transgenic animals.

To address this issue, $\mathrm{E} \mu$-Myc transgenic mice (C57BI/6) were mated with either WT or $\mathrm{MIF}^{-/-}$mice (129Sv) to obtain the F2 generations of $\mathrm{MIF}^{+/+}(\mathrm{MIF}-\mathrm{WT}), \mathrm{MIF}^{+/-}$, and $\mathrm{MIF}^{-/-}$ (MIF-KO) $\mathrm{E} \mu$-Myc animals. On this genetic background, most MIF-WT E $\mu$-Myc mice developed lethal B cell lymphomas within 2-4 months of birth (Figure 1a, curve I). Although the loss of one MIF allele had no statistically significant effect on tumor formation in this system (Figure 1a, curve II), the loss of both MIF alleles markedly protected $\mathrm{E} \mu$-Myc transgenic mice from developing lymphomas (Figure 1a, curve III). Thus, MIF$\mathrm{KO} \mathrm{E} \mu$-Myc animals exhibited a mean survival of $3.6 \pm 1.2$ months compared to $2.6 \pm 1.1$ months of the corresponding MIF-WT mice $(P<0.0009)$. In addition, $33 \%$ of MIF-KO $\mathrm{E} \mu$ Myc mice were tumor free at the age of 6 months compared to only $8 \%$ of MIF-WT E $\mu$-Myc animals (Figure 1a). The latent period before the onset of frank disease in $\mathrm{E} \mu$-Myc mice reflects the ability of $c-M y c$ to induce the p53-dependent growth arrest and apoptotic programs. ${ }^{31,32}$ In agreement with this, heterozygous $\mathrm{p} 53^{+/-} \mathrm{E} \mu$-Myc animals developed tumors and died more rapidly compared to the corresponding $\mathrm{p} 53^{+/+}$ controls (average survival $1.1 \pm 0.2$ months, Figure 1a). It should be noted that $\mathrm{p} 53^{-1-} \mathrm{E} \mu$-Myc mice are not viable as they die in utero and therefore cannot be analyzed. ${ }^{31,32}$ To this end, we were unable to produce sufficient numbers of $\mathrm{p} 53^{+/-}$ $\mathrm{MIF}^{-1-} \mathrm{E} \mu$-Myc mice because of the reduced fertility of MIF/ p53 double mutant animals. However, collectively these results suggest that MIF deficiency enhances the activity of the p53 tumor suppressor pathway in vivo.

\section{MIF-deficient $E \mu$-Myc B cells are predisposed to increased apoptosis}

Consistent with previous studies on tumor distribution in $\mathrm{E}_{\mu \text { - }}$ Myc mice, ${ }^{31-34}$ MIF-KO lymphomas involved many of the peripheral lymph nodes, including branchial, cervical, inguinal, and mesenteric sites. Flow cytometric analysis revealed that MIF-KO tumors were $\mathrm{B}^{2} 20^{+} \mathrm{IgM}^{-}$pre-B-cell lymphomas and $\mathrm{B}_{22} \mathrm{C}^{+} \mathrm{IgM}^{+}$mature B-cell lymphomas (Figure $1 \mathrm{~b}$ ), again similar to tumors from $\mathrm{E}_{\mu}$-Myc mice. ${ }^{31-34}$ Despite these similarities, MIF-deficient lymphomas displayed more pronounced 'starry sky' morphology, indicative of the extensive apoptosis (Figure 1c, d, and Supplementary Figure 1a). In situ TUNEL analysis of representative tumor sections confirmed that apoptosis levels were higher in lymphomas derived from MIF-KO E $\mu$-Myc mice (Supplementary Figure 1b). To further test if increased apoptosis is associated with MIF loss, we performed in situ TUNEL assays in tissues from young premalignant $\mathrm{E} \mu$-Myc mice of different MIF genotypes and from age-matched nontransgenic animals. Although bone marrow and spleen sections from MIFWT E $\mu$-Myc mice displayed higher levels of apoptosis relative to nontransgenic B cells, loss of MIF led to further increase in apoptosis in both tissues (Figure 2a and Supplementary Figure 2a, b). Moreover, immunoblot analysis demonstrated that splenocytes of premalignant MIF-KO E $\mu$-Myc mice expressed higher levels of the apoptotic mediators Apaf- 1 and Caspase- 3 than the a

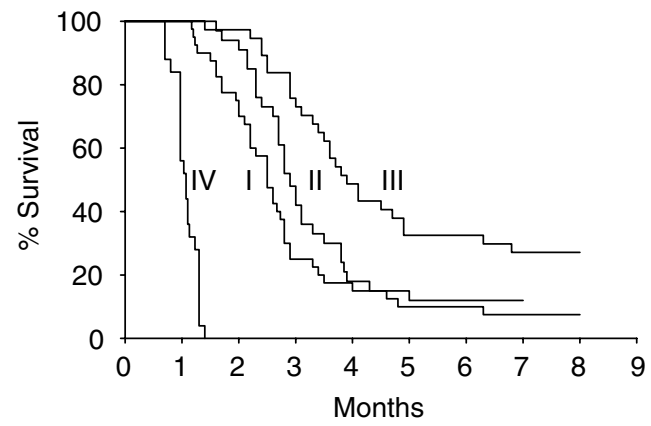

b
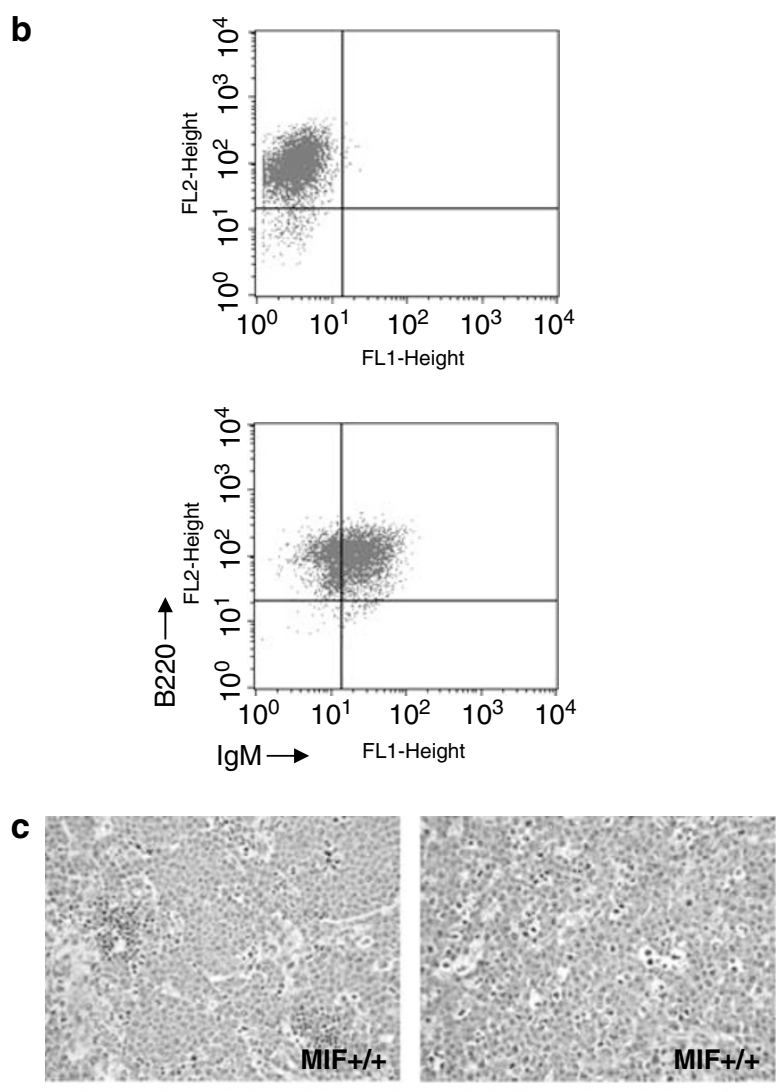

d

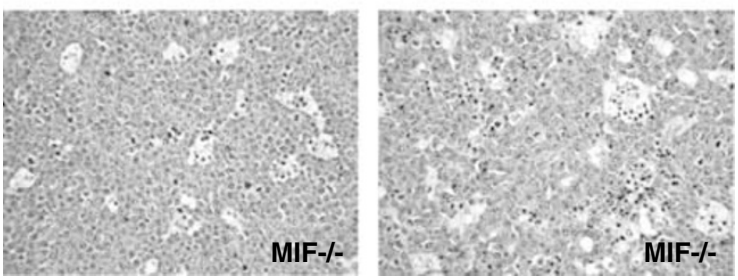

Figure 1 Loss of MIF impairs Myc-induced lymphomagenesis. (a) The survival curves for $\mathrm{E} \mu$-Myc transgenic mice of the corresponding genotypes: $\mathrm{MIF}^{+1+}(\mathrm{I}$, $n=40$ animals), $\mathrm{MIF}^{+1-}$ (II, $\left.n=33\right), \mathrm{MIF}^{-l-}(\mathrm{III}, n=37)$, and $\mathrm{p} 53^{+1-}$ (IV, $n=25)$. The average life spans of $\mathrm{MIF}^{+l+}, \mathrm{MIF}^{+l^{-}}, \mathrm{MIF}^{-{ }^{-}}$, and $\mathrm{p5} 3^{+1-} \mathrm{E} \mu-$ Myc mice were 2.6, 3.0, 3.6, and 1.1 months, respectively. (b) Flow cytometric analysis of B220 and IgM expression by two representative $\mathrm{MIF}^{-1-} \mathrm{E} \mu$-Myc tumors. (c and d) Morphology of representative lymphomas arising in $\mathrm{MIF}^{+1+}$ (c) and $\mathrm{MIF}^{-1-}$ (d) $\mathrm{E} \mu$-Myc mice. 'Starry sky' refers to focal areas of apoptosis with dying cells being phagocytosed by macrophages (magnification $\times 40$ )

respective MIF-WT controls (Figure $2 b$ ). On the other hand, loss of MIF resulted in elevation of p21 expression (Figure $2 b$ ), reduced levels of E2F-regulated gene products CDC6 and 
a

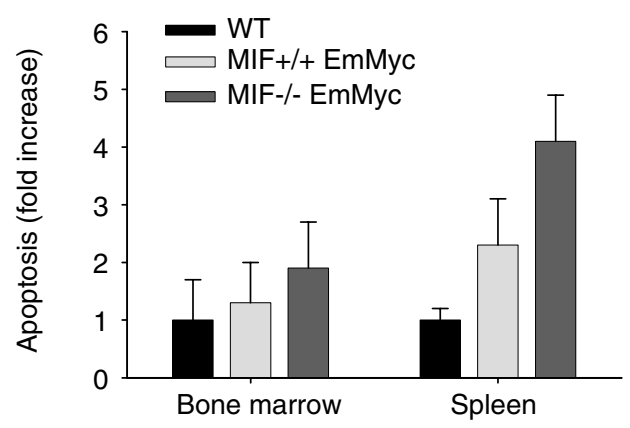

C
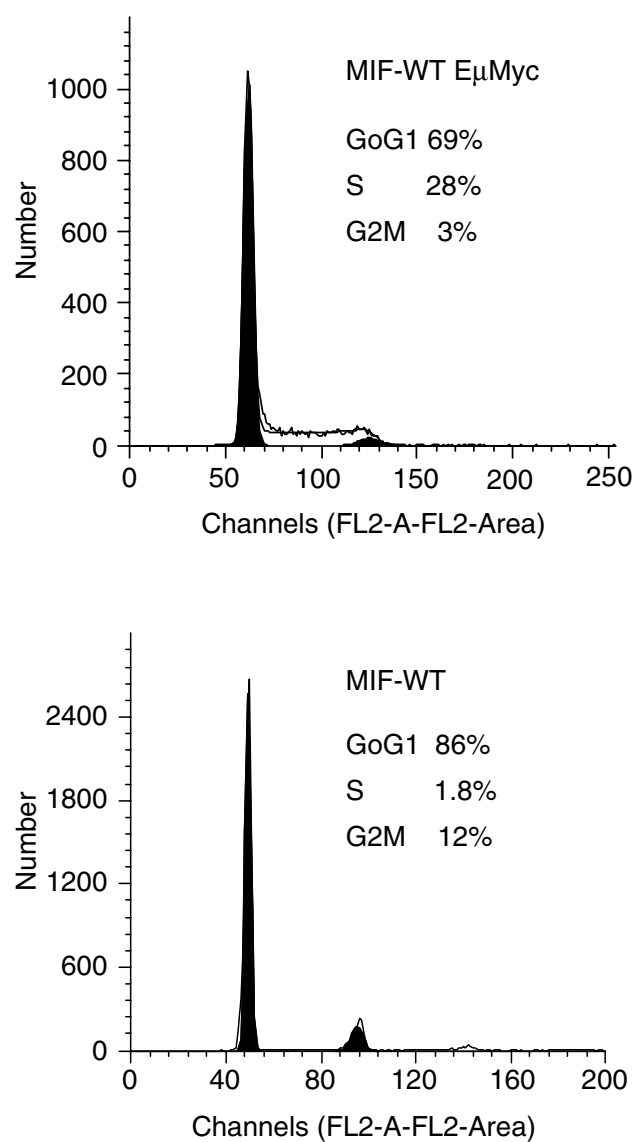

b

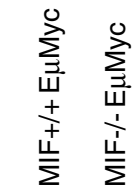

p53

Apaf-1

Caspase-3

p21

CDC2

CDC6

CDK4
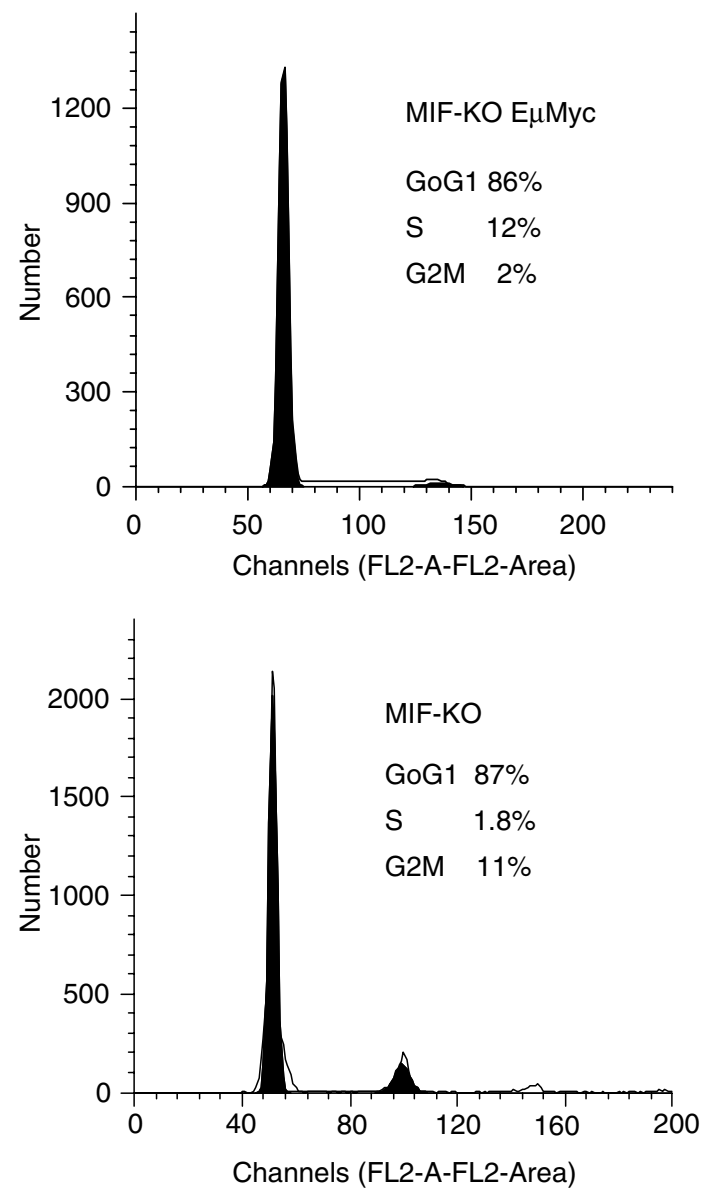

Figure 2 MIF deficiency impairs the ability of $\mathrm{E} \mu$-Myc B cells to enter $\mathrm{S}$ phase and proliferate. (a) Increase in the proportion of TUNEL-positive cells in the bone marrow and spleen cells of premalignant MIF-WT and MIF-KO E $\mu$-Myc mice relative to the corresponding tissues from WT mice. The average values from three mice of each genotype are shown. Error bars represent the standard deviation. (b) Immunoblot analysis of splenocytes derived from premalignant MIF-WT and MIF-KO E $\mu$-Myc mice. (c) Flow cytometric analysis of cell-cycle distribution of splenocytes derived from premalignant MIF-WT and MIF-KO E $\mu$-Myc mice (top) and from nontransgenic MIF-WT and MIF-KO mice (bottom). The results are representative of three examined mice of each genotype. (d) Flow cytometric analysis of B-lymphocytes derived from the lymph nodes of MIF-WT, MIFKO, $\mathrm{p5}^{-1-}$, and DKO mice. The results are representative of five independent experiments for each genotype

CDC2, which are required for DNA replication and mitosis, respectively (Figure $2 \mathrm{~b}$ ), and a lower S-phase fraction in premalignant splenocytes (Figure $2 \mathrm{c}$ ). These results imply that loss of MIF coincides with p53 induction, which in turn impinges on the ability of E $\mu$-Myc B-cells to enter $\mathrm{S}$ phase and proliferate. Therefore, inhibited progression through $S$ phase 

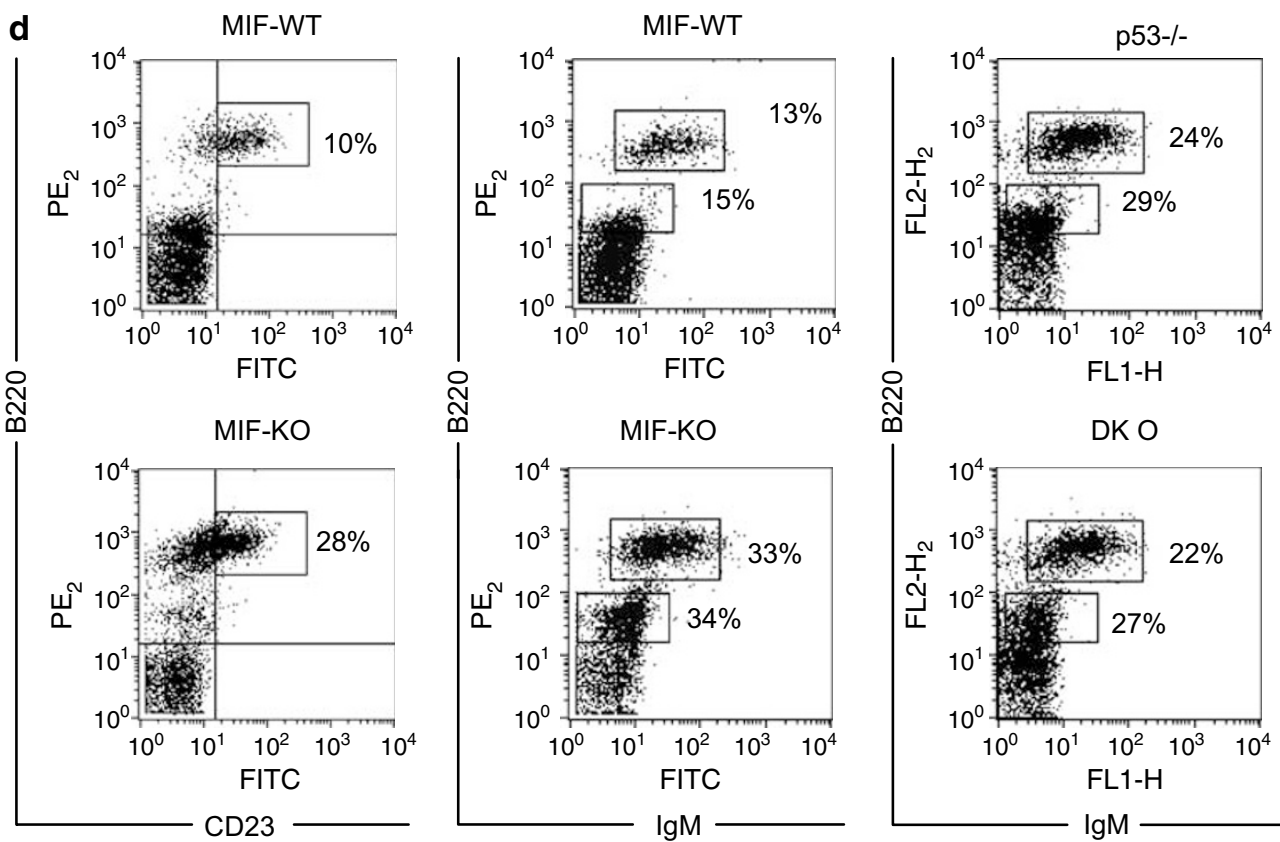

Figure 2 (Continued)

is likely at the root of the predisposition of MIF-KO $\mathrm{E} \mu$-Myc B-cells to undergo apoptosis. Consistent with this view, increased B-cell apoptosis was previously observed in E2F1/E2F2 mutant mice as a result of improper coordination between the cell cycle progression and differentiation. ${ }^{28}$

To test the possibility that the observed differences in B-cells lacking MIF were independent of $\mathrm{E} \mu$-Myc expression, we investigated cells derived from the lymphoid organs of nontransgenic animals. The cell cycle distribution of nontransgenic MIF-WT and MIF-KO splenocytes differed insignificantly (Figure 2c). Yet, the spleens and lymph nodes of MIF-KO mice contained a large proportion of immature Blymphocytes compared to MIF-WT controls, irrespective of $\mathrm{E} \mu$-Myc expression (Figure 2d). These accumulated immature B-cells are characterized by the expression of early differentiation markers CD23, CD43, AA4.1 (CD93), and IgM (Figure 2d, left panels and data not shown). Thus, we conclude that MIF-deficiency affects normal B-cell differentiation. Importantly, the differentiation defect of MIF-deficient B-cells was eliminated by codeleting p53 in MIF/p53 double knockout mice (DKO) (Figure 2d, right panel and data not shown), implicating enhanced p53 activity in mediating the differentiation block of B-cells.

\section{MIF deficiency alters the DNA-binding properties of E2F transcription factors}

The antiproliferative activities of the p53 tumor suppressor can be mediated by the E2F family of transcription factors, which function both upstream and downstream of p53 regulation. ${ }^{35,36}$ We recently showed that loss of MIF reduces the capacity for E2Fs to activate DNA replication, thereby impairing proliferation. ${ }^{25}$ Therefore, we examined promoter occupancy of individual E2Fs in splenocytes from nontransgenic and $\mathrm{E} \mu$-Myc mice of different MIF genotypes. For E2F1, chromatin immunoprecipitation (ChIP) analysis revealed insignificant in vivo binding to $c d c 2$ and $c d c 6$ promoters (Figure 3a) in splenocytes of nontransgenic mice (lanes 1 and 2) and of premalignant $\mathrm{E} \mu$-Myc animals (lanes 3 and 4). However, E2F3 and E2F4 binding differed between the two genotypes. Thus, premalignant MIF-WT E $\mu$-Myc splenocytes showed increased levels of E2F3 bound to the $c d c 2$ and $c d c 6$ promoters (Figure $3 \mathrm{a}$, lane 3 ), whereas the corresponding MIF-KO cells showed increased E2F4 binding to these promoters (Figure $3 a$, lane 4), which mirrors the reduced CDC2 and CDC6 protein levels in MIF-KO cells (Figure 2b). Importantly, this MIF-dependent behavior of E2Fs was retained in frank lymphomas. Thus, ChIP analysis revealed reduced binding of E2F1 and E2F3 to the cdc2, cdc6, and p107 promoters in MIF-KO E $\mu$-Myc lymphomas (Figure 3b, c). By contrast, the levels of promoter-bound E2F4 varied among different tumor isolates (Figure $3 d$ and data not shown). Of note, however, these differences in promoter binding were not due to protein variations, since tumors from $\mathrm{E} \mu$-Myc transgenic MIF-WT and MIF-KO mice contained similar levels of DP1, E2F1, E2F3, and E2F4, as apparent from immunoblot analysis of independent lymphoma isolates (Supplementary Figure 3a).

\section{MIF-deficient lymphomas contain p53 inactivating mutations and frequent ARF deletions}

We next assessed the functional status of the ARF-p53 axis in MIF-KO E $\mu$-Myc lymphomas. Previous studies demonstrated that the majority of tumors (50-60\%) arising in $\mathrm{E} \mu-\mathrm{Myc}$ transgenic mice sustain p53 mutations or biallelic ARF 

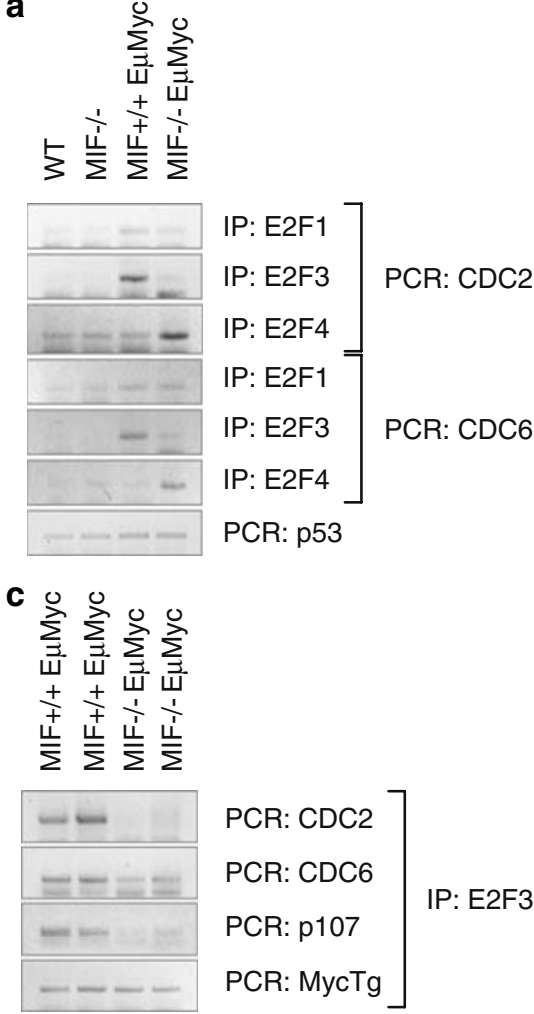

b
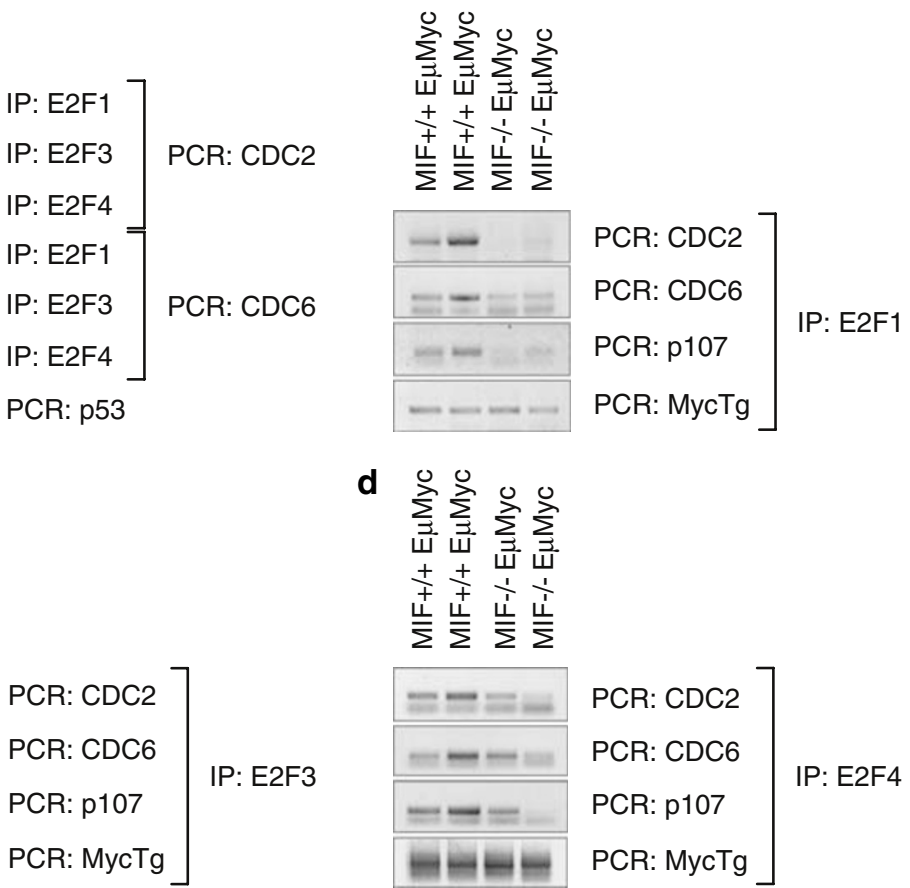

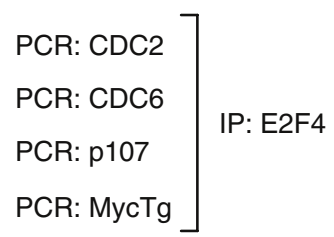

Figure 3 MIF deficiency alters the DNA-binding properties of E2F transcription factors. (a) ChIP analysis of E2F1, E2F3, and E2F4 promoter occupancy in splenocytes of WT, MIF-KO, and premalignant MIF-WT and MIF-KO E $\mu$-Myc mice. p53 is a control for equal input into PCR reactions. (b-d) ChIP analyses of E2F1 (b), E2F3 (c) and E2F4 (d) promoter occupancy in MIF-WT and MIF-KO E $\mu$-Myc lymphomas. Two independent lymphoma isolates for each genotype are shown. MycTg is a control for equal input into PCR reactions

deletion, almost always in a mutually exclusive fashion. ${ }^{31-35}$ The exact mechanism of acquisition of such mutations is presently unknown, although it likely involves Myc-induced genomic instability. ${ }^{37}$ Immunoblot analysis revealed that seven out of 24 examined MIF-KO E $\mu$-Myc tumors (29\%) contained elevated levels of p53, indicative of p53 mutations (examples in Figure $4 a$ and Supplementary Figure 4a). To confirm that these tumors have acquired mutations in p53regulated checkpoints, three out of seven lymphomas (tumors no. 4, 7 and 9 of Figure 4a) were treated with DNA-damaging agents, etoposide or adriamycin, and the proportion of apoptotic cells was evaluated by TUNEL assay. For controls, we used previously characterized ARF-negative and p53negative $\mathrm{E} \mu$-Myc lymphoma cells. In contrast to ARF-negative lymphoma cells that contain wild-type p53 (tumor isolate C1 in Figure 4a, b), p53-null lymphoma showed only a modest increase in apoptotic cells after DNA damage (Figure 4c). Similarly, the pooled MIF-KO E $\mu$-Myc lymphomas showed an equally modest increase in the proportion of apoptotic cells (Figure 4c), implying that they indeed had acquired mutations that compromise p53 function.

Out of the 24 tumors derived from MIF-KO E $\mu$-Myc mice, 15 $(63 \%)$ were ARF-negative, reflecting a strong selective pressure against ARF function (examples in Figure $4 a$ and Supplementary Figure $4 \mathrm{a}$ ). By contrast, $78 \%$ of tumors developed by MIF-WT E $\mu$-Myc animals retained ARF expres- sion (Figure 4b and Supplementary Figure 4b), which is consistent with the previously reported frequency of ARF mutations in $\mathrm{E}_{\mu}$-Myc mice. ${ }^{31,32}$ Although ARF-deficient lymphomas generally display reduced p53 activity, ${ }^{31,32}$ genomic PCR using p53-specific primers revealed that $30 \%$ (two out of six examined tumors) of ARF-negative MIF-KO E $\mu$ Myc lymphomas have concomitantly sustained deletions of the p53 gene (Supplementary Figure 4c). Recent studies demonstrated that the ARF tumor suppressor inhibits cell cycle through p53-dependent and p53-independent mechanisms. ${ }^{38-43}$ Moreover, ARF/p53 double-null B cells are more resistant to Myc-induced apoptosis than cells lacking ARF or p53 alone. ${ }^{31}$ At face value, these results imply that the p53independent ARF function might be selected against in MIF$\mathrm{KO} \mathrm{E} \mu$-Myc B-lymphomas. However, lymphoma lines established from ARF-negative $E_{\mu}$-Myc tumors proliferated at faster rates compared to ARF-positive $\mathrm{E} \mu$-Myc lymphoma cells, irrespective of the MIF status (Figure 4d). One explanation for this is that while ARF is not induced by DNA damage, it still can potentiate p53-dependent DNA damage responses that occur in the setting of Myc-induced genomic instability. $32,41,42$

Frequencies of $\mathrm{p} 53$ and ARF mutations in MIF-KO E $\mu$-Myc mice are summarized in Table 1 . Considering that only $67 \%$ of MIF-KO E $\mu$-Myc mice developed tumors by the age of 6 months (Figure 1a), 19\% of animals acquired p53 mutations in 
a

MIF-KO E $\mu-M y c$

Tumor \# $\begin{array}{lllllllllll}1 & 2 & 3 & 4 & 5 & 6 & 7 & 8 & 9 & \mathrm{C} 1 & \mathrm{C} 2\end{array}$

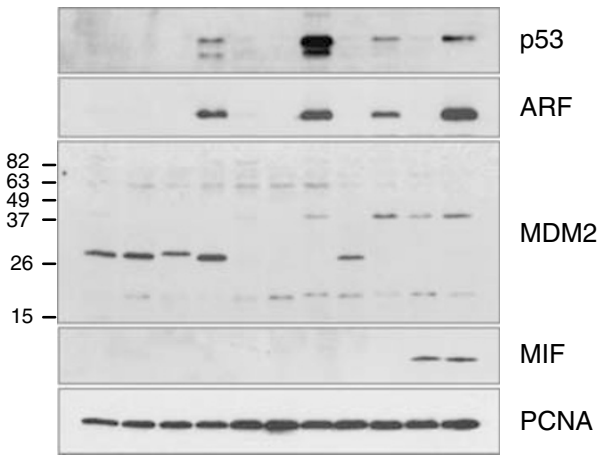

b MIF-WT E $\mu-M y c$
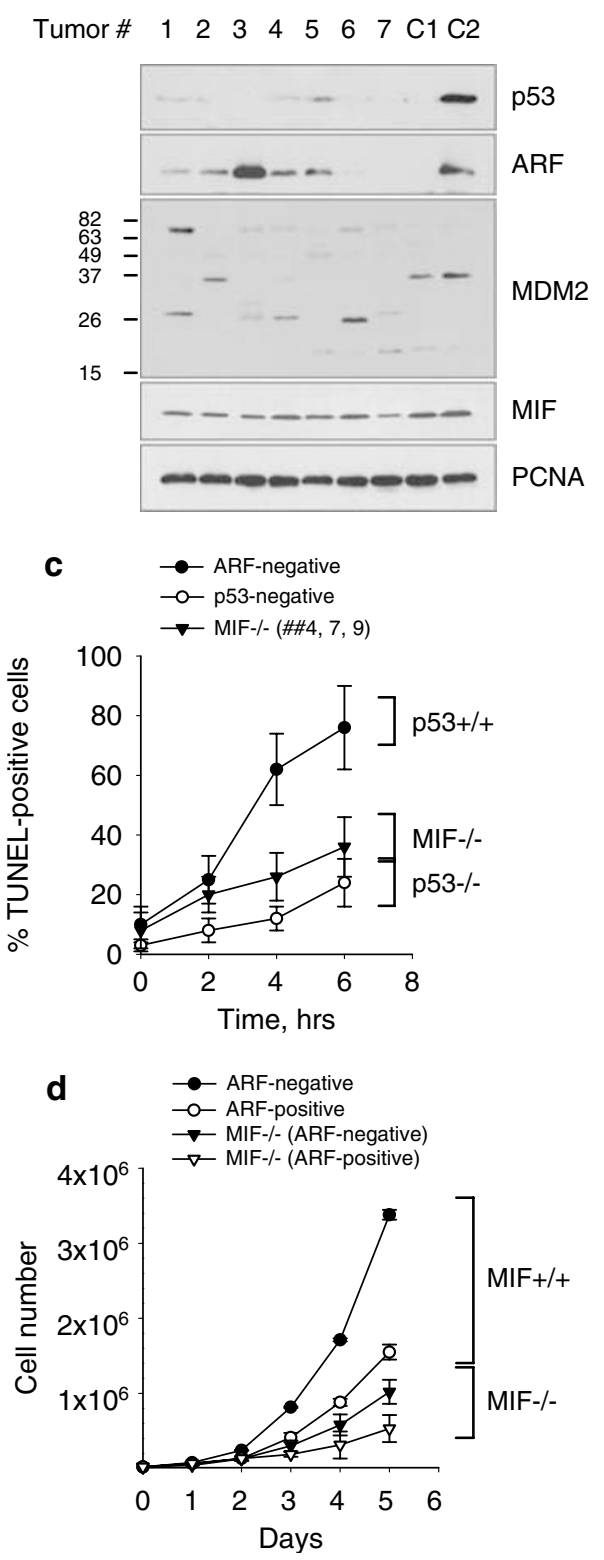

Table 1 Frequencies of $\mathrm{p} 53$ and ARF mutations in MIF-KO E $\mu$-Myc transgenic mice

\begin{tabular}{lcc}
\hline Genotype & $\begin{array}{c}\text { MIF-WT E } \mu \text { - } \\
\text { Myc (\%) }\end{array}$ & $\begin{array}{c}\text { MIF-KO E } \mu \text { - } \\
\text { Myc (\%) }\end{array}$ \\
\hline Mice with tumors & 92 & 67 \\
p53 mutation & $\sim 30^{\mathrm{a}}$ & $19^{\mathrm{a}}$ \\
Biallelic ARF & 20 & 29 \\
deletion & $\sim 0^{31-35}$ & 13 \\
Compound p53/ARF & & \\
\hline loss & & \\
\hline
\end{tabular}

${ }^{\mathrm{a}}$ Frequencies of mutations based on elevated p53 levels in tumor isolates.

their B-cell compartment, while $29 \%$ sustained biallelic loss of ARF, and $13 \%$ developed tumors with compound p53 and ARF mutations. It has been shown that mechanisms other than p53 mutation or deletion, ARF loss, or Mdm2 overexpression contribute to disease in at least $20 \%$ of the $\mathrm{E} \mu$ Myc-induced tumors. ${ }^{31-34}$ On the other hand, 22 out of 24 tumors (92\%) in MIF-KO E $\mu$-Myc mice sustained mutations specifically affecting either ARF or p53. Thus, in contrast to MIF-WT E $\mu$-Myc tumors, in MIF deficiency almost all tumors can be accounted for by mutations within the ARF-p53 axis, indicating that the p53 pathway is the main determinant for tumor suppression.

Immunoblot analysis showed that most of the MIF-KO and MIF-WT E $\mu$-Myc tumors expressed variant Mdm2 isoforms, reactive with an $M d m 2$ antibody raised against amino acids 154-167 of the protein (Figure 4a, b). This is consistent with previous reports that $\mathrm{E} \mu$-Myc induced tumors frequently overexpress Mdm2 or its variant splice isoforms, irrespective of whether they have retained functional ARF or p53 genes. $^{44,45}$ To date, nearly 40 cancer-associated Mdm2 splice variants have been identified. ${ }^{46}$ The functional significance of many Mdm2 isoforms has not been established, as recent studies have shown that at least some Mdm2 splice variants have tumor-promoting activity, ${ }^{45}$ while others promote p53-mediated growth arrest. ${ }^{44}$ Of note, however, MIF$\mathrm{KO}$ lymphomas did not express detectable full-length Mdm2 or the p76Mdm2 isoform (Figure $4 a$ and data not shown). The p76 isoform has previously been shown to inhibit the ability of full-length Mdm2 to destabilize p53. ${ }^{47}$ Other mediators of Myc induced apoptosis, such as Bcl2, Bak, Bax, Bcl-xl, and Bcl-xs were variably expressed in MIF KO lymphomas (Supplementary Figure 4a).

Figure 4 MIF-deficient lymphomas contain p53 inactivating mutations and frequent ARF deletions. (a) Immunoblot analysis of lymphomas arising in MIF$\mathrm{KO} \mathrm{E} \mu$-Myc mice. For controls, ARF-negative and mutant p53 H279P-expressing $\mathrm{E} \mu$-Myc B-lymphomas (tumor isolates $\mathrm{C} 1$ and $\mathrm{C} 2$, respectively) are shown. PCNA is a loading control. (b) Immunoblot analysis of lymphomas arising in MIFWT E $\mu$-Myc mice. (c) B-cell cultures established from three p53-expressing MIF$\mathrm{KO} \mathrm{E} \mu$-Myc-induced tumors were pooled and treated with $5 \mu \mathrm{M}$ etoposide for up to $6 \mathrm{~h}$ and the proportion of apoptotic cells was evaluated by TUNEL assay. ARFnegative (p53-positive) and p53-negative (ARF-positive) E $\mu$-Myc lymphoma cells were used as controls. (d) Growth curves of lymphomas of the indicated genotypes. Loss of ARF confers growth advantage independent of MIF. The average values of two independent lymphoma isolates for each genotype are shown. Error bars represent the standard deviation 
Combined, these results indicate that the overall spectrum of alterations in MIF-KO lymphomas is consistent with previous observations on $\mathrm{E} \mu$-Myc mice.$^{31-35}$ Moreover, ARF and p53 loss of function contribute to the majority of the Mycinduced lymphomas arising in MIF-KO animals. However, MIF-KO tumors exhibit a significantly higher frequency of ARF mutations (approximately threefold) than MIF-WT tumors. Of note, MIF expression was retained in tumors arising in MIFWT E $\mu$-Myc mice (Figure 4b and Supplementary Figure 4b). Also, lymphoma lines established from these tumors expressed MIF protein at levels similar to WT fibroblasts (data not shown).

\section{MIF deficiency does not perturb the expression of Myc target genes}

We next evaluated the requirement for MIF in Myc-regulated transcriptional activation. Because of the variable nature of mutations in $\mathrm{E} \mu$-Myc lymphomas, we used primary fibroblasts isolated from MIF-WT, MIF-KO, p53 ${ }^{-1-}$, and DKO embryos for this purpose. MEFs of the indicated genotypes were infected with recombinant retroviruses expressing Myc and examined in various cell-based assays. Immunoblot analysis of virally transduced WT and MIF-KO fibroblasts showed equivalent expression levels of the exogenous Myc protein (Figure 5a). The levels of the key functional targets of Myc regulation, such as Cyclin A, Cyclin E, CDK2, CDK4, and p27, were also similar between the two genotypes (Supplementary Figure 3c). Equivalent levels of these proteins were also

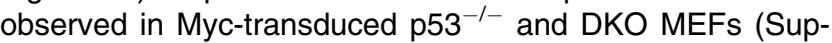
plementary Figure 3d). In addition, semiquantitative RT-PCR analysis of Myc-transduced $\mathrm{p} 53^{-1-}$ and DKO MEFs showed equivalent expression levels of Myc target genes CAD, GADD45, and TERT (data not shown). These results indicate that MIF deficiency does not perturb the expression of many Myc target genes. However, the levels of p21 and Apaf-1, downstream targets of p53 regulation, were higher in Myctransduced MIF-KO cells than WT cells (Figure 5a), reflecting their higher p53 activity.
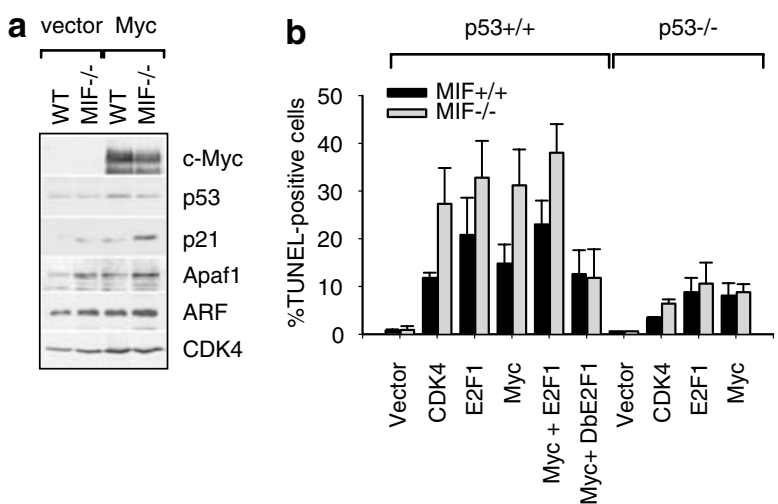

Figure 5 Loss of MIF enhances E2F1-mediated apoptosis. (a) Immunoblot analysis of Myc-transduced WT and MIF-KO MEFs. CDK4 is a loading control. (b) MEFs of the indicated genotypes were infected with Myc-, CDK4-, E2F1-, or DbE2F1- expressing retroviruses and maintained in serum-free media for 2 days. The proportion of apoptotic cells was measured by TUNEL assay. The average values from three independent experiments are shown. Error bars represent the standard deviation

\section{Loss of MIF enhances p53- and E2F1-mediated apoptosis}

Myc-induced apoptosis in fibroblasts can be triggered by deprivation of serum survival factors. ${ }^{17,48}$ In several independent experiments, Myc-induced apoptosis was increased approximately two-fold by the loss of MIF and was alleviated on the p53 null background (Figure 5b). Similar results were obtained using cyclin-dependent kinase 4 (CDK4)- and E2F1transduced fibroblasts (Figure $5 \mathrm{~b}$ ). However, expression of the dominant-negative E2F1 mutant (DbE2F1) which lacks the C-terminal transactivation and Rb-binding domains ${ }^{25,36}$ suppressed the apoptotic response of Myc-transduced MIF$\mathrm{KO}$ cells down to the level of WT cells (Figure $5 \mathrm{~b}$ ). Both Myc and CDK4 induce $\mathrm{Rb}$ inactivation, followed by the release of free E2Fs. ${ }^{49,50}$ Thus, these results indicate that MIF-deficient cells are hypersensitive to E2F1 upregulation with respect to apoptosis, and this effect can be abolished by codeleting p53.

\section{Discussion}

Traditionally, the major focus of MIF research has been on its role as a proinflammatory mediator within the immune system. ${ }^{10,11}$ However, based on the recently observed correlation of MIF expression levels and tumor aggressiveness it was proposed that MIF might also serve as a link between inflammation and cancer. ${ }^{12-17}$ Within the hematopoietic system, MIF is expressed by several cell types, including B-lymphoid, ${ }^{51}$ T-lymphoid, ${ }^{52}$ myeloid, ${ }^{53,54}$ and erythroid progenitor cells (OP, unpublished). Here, we provide direct evidence for MIF's involvement in malignant processes in vivo. Using the $\mathrm{E} \mu$-Myc tansgenic mouse model, we demonstrate that loss of MIF delays the onset of B-cell lymphoma development. We further show that MIF-deficient premalignant $\mathrm{E} \mu$-Myc B cells are predisposed to delayed Sphase progression and increased apoptosis. The perturbed DNA-binding by E2F factors and the concomitantly enhanced activity of the p53 tumor suppressor pathway are at the root of this MIF-loss-induced phenotype.

A functional link between MIF and p53 has been suggested in previous studies. ${ }^{17,18,23}$ The data presented here implicate E2Fs in mediating this MIF-p53 connection. As we recently showed, loss of MIF augments Rb-mediated repression of E2F responsive genes and reduces the capacity for E2Fs to activate DNA replication, thereby impairing proliferation. ${ }^{25}$ On the other hand, the proliferative response of Myc-overexpressing cells depends on the induction and activation of E2F factors, ${ }^{35,55,56}$ although E2F thresholds (in particular E2F1) also determine whether cells live or die. ${ }^{55-58}$ It should be noted, however, that although both Myc and E2F1 can function as parts of multiprotein complexes that activate or repress cellular genes, neither has yet been shown to induce p53 directly. While early work suggested existence of a linear E2F1-ARF-p53 axis, more recent studies instead demonstrated that E2F1 and ARF act in parallel pathways that activate $p 53$ in response to oncogenic signaling. ${ }^{57,58}$ In view of the fact that continuing E2F activity is required for S-phase progression and the survival of Myc-overexpressing cells, ${ }^{35,56}$ loss of the Ink4A/ARF locus therefore provides a selective advantage to tumor cells, while loss of E2Fs does not. 
Moreover, because p53 is more frequently mutated rather than deleted in $E \mu$-Myc lymphomas, ${ }^{31,32}$ ARF loss has stronger detrimental consequences for p53 inactivation than p53 point mutations.

Given that several members of the E2F family exhibit overlapping properties and collectively play complex roles in normal development and neoplastic disease, ${ }^{59,60}$ our data imply that the involvement of MIF in tumorigenic processes may depend on variable roles of E2Fs in different tissues. For example, E2F1, the best characterized member of the E2F family, has displayed properties of both a proto-oncogene and a tumor suppressor in different experimental settings and tissue types. ${ }^{59,60}$ Although the tumor-promoting and tumorsuppressive properties of E2F1 are not understood completely, they are traditionally believed to result from its ability to influence the levels apoptosis, which can be both p53dependent and p53-independent. ${ }^{59,60}$ Indeed, the prevailing model of E2F regulation involves its inhibition by the $\mathrm{Rb}$ family proteins, while free E2F1 constitutes an oncogenic stress that activates p53. ${ }^{59,60}$ However, a growing body of evidence supports an alternative view where E2Fs co-operate with $\mathrm{Rb}$ in active repressor complexes that regulate cell cycle progression through association with cofactors, such as HDAC or BRG/BRM, and the subsequent modulation of chromatin. ${ }^{60,61}$

In support of the latter, interference with E2F-mediated transcriptional regulation through a dominant-negative mutant caused a general derepression of E2F-responsive genes, implying a predominant repressor role of endogenous E2Fs in cultured cells. ${ }^{25,36,62}$ Moreover, Myc-induced p53-dependent apoptosis is increased in the epithelium of mice lacking $\mathrm{E} 2 \mathrm{~F} 1,{ }^{63}$ while the role of E2F1 in mediating tumorigenesis can be explained by its ability to suppress rather than induce apoptosis. ${ }^{64-66}$ Collectively, these data imply that E2Fs play complex roles in gene regulation and that apoptotic target genes of E2F1, such as p73, Apaf-1, and procaspases, may be downregulated (rather than upregulated) by E2F1 in vivo, while p53 acts to relieve this expression block. Consistent with this view, DNA binding is required for E2F1-responsive apoptosis, whereas transactivation is largely dispensable. ${ }^{65,66}$ Strikingly, this does not seem to be the case in MIF deficiency, as our data with DbE2F1 clearly indicate that the growth- and apoptosis-promoting E2F1 activity in MIF null cells depends on the presence of its C-terminal Rb-binding/ transactivation domain. Because $\mathrm{Rb}$ and its family proteins are largely inactive in Myc- or E2F-overexpressing cells, ${ }^{49,50,56}$ we speculate that an $\mathrm{Rb}$-independent inhibitor of E2F1 is lost in MIF-deficient cells, explaining why ectopic E2F1 has more effect in MIF-KO than WT fibroblasts. Clearly, further analysis is required to identify which endogenous proteins might interact with E2F1 that could determine its proor anti-apoptotic properties in the context of MIF deficiency.

\section{Materials and Methods}

\section{Mice and tissue culture}

The generation of MIF-knockout mice was described previously. ${ }^{23} \mathrm{MIF}^{+1-}$ $\mathrm{p} 53^{+1-}$ double heterozygous mice were derived by crossing between the $\mathrm{MIF}^{-1-}$ and Trp53 ${ }^{\text {tm1Tyj }}$ animals (Jackson Laboratory), both on the 129S1/

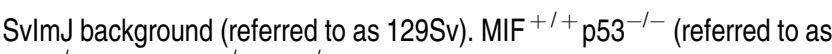
$\mathrm{p} 53^{-1-}$ ) and $\mathrm{MIF}^{-1-} \mathrm{p} 53^{-1-}$ (DKO) mice were derived from crosses between the double heterozygous animals. Wild-type, $\mathrm{MIF}^{-1-}$ and $p 53^{-1-}$ mice (all 129Sv) were interbred with a C57BI/6 strain of $\mathrm{E} \mu$ Myc transgenic mice ${ }^{26,27}$ to obtain the F2 generations of $\mathrm{MIF}^{+/+}, \mathrm{MIF}^{+/-}$, $\mathrm{MIF}^{-1-}$, and $\mathrm{p} 53^{+/-}$transgenic animals. The genotype of mice was verified by PCR amplification specific for the corresponding Wild type (WT) and mutant alleles. ${ }^{23}$ All animals were genotyped twice, at the time of weaning and when sacrificed. Mice were observed daily for precipitous changes in health and tumor development. Tumors that arose were harvested and processed for histological examination and protein analysis. Student's t-test was used to determine statistical significance.

Splenocytes from nontransgenic and premalignant $\mathrm{E} \mu$-Myc mice of different MIF genotypes were derived as previously described. ${ }^{28}$ Typically, $\mathrm{B} 220^{+}$Thy $1^{-}$B-lymphocytes constituted up to $55 \%$ of splenic cells. Mouse embryonic fibroblasts (MEFs) were prepared from individual embryos at day 14 using standard techniques. In most experiments, MEFs were used between passages 2 and 6 . Replication-defective retroviral vectors expressing c-Myc and DbE2F1 were previously described. ${ }^{24}$ Other retroviral vectors included those encoding CDK4, E2F1, and E2F4. For viral infections, $10^{5}$ MEFs plated onto a $6-\mathrm{cm}$ dish were incubated overnight with an appropriate amount of the corresponding retroviral stock. Cells were analyzed for the corresponding protein levels 3-4 days postinfection.

\section{Expression analysis}

Semiquantitative RT-PCR was performed using whole cell RNAs prepared from exponentially growing MEFs and previously described oligonucleotide primers specific for GAPDH, CAD, GADD45, and TERT ${ }^{29}$ For protein analysis, aliquots of whole-cell or nuclear lysates $(50-80 \mu \mathrm{g}$ of protein) were separated on SDS-acrylamide gels and blotted onto a Protran BA85 nitrocellulose membrane (Schleicher \& Schüll). They were then incubated with antibodies specific for p53 (CM-5, Novocastra), p21 (C-19), Mdm2 (SMP14), Bax (B-9), Bcl-xl (S-18), cyclin E (M-20), E2F1 (KH-95 and C-20), c-Myc (N-262), PCNA (F-2), (all from Santa Cruz Biotechnology); Bak (65371, BD Pharmingen), Bcl2 (610538), Cdk2 (C18520), Cdk4 (C18720), p27 (K25020) (all from Transduction Laboratories); p19ARF (ab80, Novus Biologicals); MAPK (3A7; Cell Signaling), and MIF (a gift from C. Metz, North Shore Hospital, Manhasset, NY).

\section{Apoptosis assays}

For DNA damage checkpoint analysis, lymphoma cells isolated from MIF-positive and MIF-negative $\mathrm{E} \mu$-Myc transgenic mice were maintained in the presence of $5 \mu \mathrm{M}$ etoposide or $0.34 \mu \mathrm{M}$ adriamycin for $6 \mathrm{~h}$. Cells were fixed in $4 \%$ paraformaldehyde, and then stained using TUNEL reaction (Roche).

\section{Chromatin immunoprecipitation assays}

Chromatin immunoprecipitation (ChIP) assays were performed as previously described ${ }^{29}$ with a few modifications. The cells were fixed with $1 \%$ formaldehyde for $1 \mathrm{~h}$ at room temperature with mild shaking. To stop the fixation reaction, glycine was added to a final concentration of $0.125 \mathrm{M}$. Cells were then washed with PBS and lyzed in the IP buffer containing $10 \mathrm{mM}$ TrisHCl, $\mathrm{pH} 7.4,150 \mathrm{mM} \mathrm{NaCl}, 10 \%$ glycerol, $1 \mathrm{mM}$ EDTA, $1 \%$ Triton $\mathrm{X}-100$ and protease inhibitors (Roche). Nuclei were collected by centrifugation $(3000 \times \mathrm{g}$ for $5 \mathrm{~min})$, resuspended in the IP buffer, and sonicated five times with 10 -s pulses. Chromatin solution was 
precleared with Staphylococcus aureus protein A-containing cells for $5 \mathrm{~min}$ at $4^{\circ} \mathrm{C}$. Precleared chromatin from approximately $5 \times 10^{6}$ cells was incubated with $1 \mu \mathrm{g}$ of the indicated antibodies and $20 \mu \mathrm{l}$ of protein $\mathrm{A} / \mathrm{G}$ Sepharose at $4{ }^{\circ} \mathrm{C}$ overnight. Beads were washed with the IP buffer and eluted in the TE buffer containing $0.5 \%$ SDS, followed by reversion of the crosslinking and DNA isolation by phenol extraction. Eluted material was subjected to semiquantitative PCR amplification, which was performed using the following primers: $5^{\prime}$-tagtggactgtcactttggtgg and $5^{\prime}$-cgccaatccga ttgcacgtaga for CDC2; $5^{\prime}$-cacttcccgccaggctttac and $5^{\prime}$-ccgctctccaccggtt gctc for CDC6; 5'-ttagagtccgaggtccatcttct and $5^{\prime}$-gggctcgtcctcgaacatatcc for p107. To normalize samples by the amount of nonspecific DNA, we amplified the Myc transgene region and/or p53, the primer sequences for which were provided by The Jackson Laboratory.

\section{Flow cytometric analysis}

Immunophenotyping was performed on MIF-positive and MIF-negative lymphomas using CD23, CD43, B220 (CD45R), IgM, and IgD antibodies (BD Pharmingen). Cells were examined on a BD FACScan analyzer with CellQuest software.

\section{Acknowledgements}

This work has been supported by the Long Island Cancer Center and grants from the National Institute of Health CA060664 and the American Cancer Society CCG-105595 to UMM. The authors have no conflicting financial interests.

\section{References}

1. Calandra $T$ and Roger $T$ (2003) Macrophage migration inhibitory factor: a regulator of innate immunity. Nat. Rev. Immunol. 3: 791-800

2. Kobayashi S, Satomura K, Levsky JM, Sreenath T, Wistow GJ, Semba I, Shum L, Slavkin HC and Kulkarni AB (1999) Expression pattern of macrophage migration inhibitory factor during embryogenesis. Mech. Dev. 84: 153-156

3. Suzuki T, Ogata A, Tashiro K, Nagashima K, Tamura M and Nishihira J (1999) Augmented expression of macrophage migration inhibitory factor (MIF) in the telencephalon of the developing rat brain. Brain Res. 816: 457-462

4. Wistow GJ, Shaughnessy MP, Lee DC, Hodin J and Zelenka PS (1993) A macrophage migration inhibitory factor is expressed in the differentiating cells of the eye lens. Proc. Natl. Acad. Sci. USA 90: 1272-1275

5. David JR (1966) Delayed hypersensitivity in vitro: its mediation by cell-free substances formed by lymphoid cell-antigen interaction. Proc. Natl. Acad. Sci. USA 56: 72-77

6. Arcuri F, Ricci C, letta F, Cintorino M, Tripodi SA, Cetin I, Garzia E, Schatz F, Klemi P, Santopietro R and Paulesu L (2001) Macrophage migration inhibitory factor in the human endometrium: expression and localization during the menstrual cycle and early pregnancy. Biol. Reprod. 64: 1200-1205

7. Morelli AE, Zahorchak AF, Larregina AT, Colvin BL, Logar AJ, Takayama T, Falo LD and Thomson AW (2001) Cytokine production by mouse myeloid dendritic cells in relation to differentiation and terminal maturation induced by lipopolysaccharide or CD40 ligation. Blood 5: 1512-1523

8. Morimoto T, Nishihira J and Kohgo T (2003) Immunohistochemical localization of macrophage migration inhibitory factor (MIF) in human gingival tissue and its pathophysiological functions. Histochem. Cell. Biol. 120: 293-298

9. Shimizu T, Nishihira J, Mizue Y, Nakamura H, Abe R, Watanabe H, Ishibashi T and Shimizu $H$ (2002) Histochemical analysis of macrophage migration inhibitory factor in psoriasis vulgaris. Histochem. Cell. Biol. 118: 251-257

10. Calandra T, Bernhagen J, Metz CN, Spiegel LA, Bacher M, Donnelly T, Cerami A and Bucala R (1995) MIF as a glucocorticoid-induced modulator of cytokine production. Nature 6544: 68-71

11. Metz CN and Bucala R (2000) MIF In Cytokine Reference Vol. I, Oppenheim J and Feldmann M, eds (New York: Academic Press) pp. 703-717
12. Campa MJ, Wang MZ, Howard B, Fitzgerald MC and Patz Jr EF (2003) Protein expression profiling identifies macrophage migration inhibitory factor and cyclophilin a as potential molecular targets in non-small cell lung cancer. Cancer Res. 63: 1652-1656

13. Markert JM, Fuller CM, Gillespie GY, Bubien JK, McLean LA, Hong RL, Lee K, Gullans SR, Mapstone TB and Benos DJ (2001) Differential gene expression profiling in human brain tumors. Physiol. Genomics 7: 21-33

14. Meyer-Siegler K (2000) Increased stability of macrophage migration inhibitory factor (MIF) in DU-145 prostate cancer cells. J. Interferon Cytokine Res. 20: 769-778

15. Tomiyasu M, Yoshino I, Suemitsu R, Okamoto T and Sugimachi K (2002) Quantification of macrophage migration inhibitory factor mRNA expression in non-small cell lung cancer tissues and its clinical significance. Clin. Cancer Res. 8: $3755-3760$

16. White ES, Flaherty KR, Carskadon S, Brant A, lannettoni MD, Yee J, Orringer MB and Arenberg DA (2003) Macrophage migration inhibitory factor and CXC chemokine expression in non-small cell lung cancer: role in angiogenesis and prognosis. Clin. Cancer Res. 9: 853-860

17. Hudson JD, Shoaibi MA, Maestro R, Carnero A, Hannon GJ and Beach DH (1999) A proinflammatory cytokine inhibits p53 tumor suppressor activity. J. Exp. Med. 190: 1375-1382

18. Mitchell RA, Liao H, Chesney J, Fingerle-Rowson G, Baugh J, David J and Bucala R (2002) Macrophage migration inhibitory factor (MIF) sustains macrophage proinflammatory function by inhibiting p53: regulatory role in the innate immune response. Proc. Natl. Acad. Sci. USA 99: 345-350

19. Kleemann R, Hausser A, Geiger G, Mischke R, Burger-Kentischer A, Flieger O, Johannes FJ, Roger T, Calandra T, Kapurniotu A, Grell M, Finkelmeier D, Brunner $\mathrm{H}$ and Bernhagen $\mathrm{J}(2000)$ Intracellular action of the cytokine MIF to modulate AP-1 activity and the cell cycle through Jab1. Nature 408: $211-216$

20. Cope GA and Deshaies RJ (2003) COP9 signalosome: a multifunctional regulator of SCF and other cullin-based ubiquitin ligases. Cell 114: 663-671

21. Tomoda K, Yoneda-Kato N, Fukumoto A, Yamanaka S and Kato JY (2004) Multiple functions of Jab1 are required for early embryonic development and growth potential in mice. J. Biol. Chem. 279: 43013-43018

22. Wolf DA, Zhou C and Wee $S$ (2003) The COP9 signalosome: an assembly and maintenance platform for cullin ubiquitin ligases? Nat. Cell. Biol. 12: 1029-1033

23. Fingerle-Rowson G, Petrenko O, Metz CN, Forsthuber TG, Mitchell R, Huss R, Moll U, Muller W and Bucala R (2003) The p53-dependent effects of macrophage migration inhibitory factor revealed by gene targeting. Proc. Natl. Acad. Sci. USA 100: 9354-9359

24. Petrenko O, Fingerle-Rowson G, Peng T, Mitchell RA and Metz CN (2003) Macrophage migration inhibitory factor deficiency is associated with altered cell growth and reduced susceptibility to Ras-mediated transformation. J. Biol. Chem. 278: 11078-11085

25. Petrenko $O$ and Moll U (2005) Macrophage migration inhibitory factor MIF interferes with the Rb-E2F pathway. Mol. Cell 17: 225-236

26. Adams JM, Harris AW, Pinkert CA, Corcoran LM, Alexander WS, Cory S, Palmiter RD and Brinster RL (1985) The c-myc oncogene driven by immunoglobulin enhancers induces lymphoid malignancy in transgenic mice. Nature 318: 533-538

27. Sidman CL, Denial TM, Marshall JD and Roths JB (1993) Multiple mechanisms of tumorigenesis in $\mathrm{E}$ mu-myc transgenic mice. Cancer Res. 53: 1665-1669

28. Li FX, Zhu JW, Hogan CJ and DeGregori J (2003) Defective gene expression, S-phase progression, and maturation during hematopoiesis in E2F1/E2F2 mutant mice. Mol. Cell. Biol. 23: 3607-3622

29. Nikiforov MA, Chandriani S, Park J, Kotenko I, Matheos D, Johnsson A, McMahon SB and Cole MD (2002) TRRAP-dependent and TRRAPindependent transcriptional activation by Myc family oncoproteins. Mol. Cell. Biol. 22: 5054-5063

30. Zindy F, Eischen CM, Randle DH, Kamijo T, Cleveland JL, Sherr CJ and Roussel MF (1998) Myc signaling via the ARF tumor suppressor regulates p53dependent apoptosis and immortalization. Genes Dev. 12: 2424-2433

31. Eischen CM, Weber JD, Roussel MF, Sherr CJ and Cleveland JL (1999) Disruption of the ARF-Mdm2-p53 tumor suppressor pathway in Myc-induced lymphomagenesis. Genes Dev. 13: 2658-2669

32. Schmitt CA, McCurrach ME, de Stanchina E, Wallace-Brodeur RR and Lowe SW (1999) INK4a/ARF mutations accelerate lymphomagenesis and promote chemoresistance by disabling p53. Genes Dev. 13: 2670-2677 
33. Jacobs JJ, Scheijen B, Voncken JW, Kieboom K, Berns A and van Lohuizen M (1999) Bmi-1 collaborates with C-Myc in tumorigenesis by inhibiting C-Mycinduced apoptosis via INK4a/ARF. Genes Dev. 13: 2678-2690

34. Eischen CM, Woo D, Roussel MF and Cleveland JL (2001) Apoptosis triggered by Mycinduced suppression of $\mathrm{Bcl}-\mathrm{X}(\mathrm{L})$ or $\mathrm{Bcl}-2$ is bypassed during lymphomagenesis. Mol. Cell Biol. 21: 5063-5070

35. Baudino TA, Maclean KH, Brennan J, Parganas E, Yang C, Aslanian A, Lees JA, Sherr CJ, Roussel MF and Cleveland JL (2003) Myc-mediated proliferation and lymphomagenesis, but not apoptosis, are compromised by E2f1 loss. Mol. Cell 11: 905-914

36. Rowland BD, Denissov SG, Douma S, Stunnenberg HG, Bernards R and Peeper DS (2002) E2F transcriptional repressor complexes are critical downstream targets of p19(ARF)/p53 induced proliferative arrest. Cancer Cell 2: $55-65$

37. Secombe J, Pierce SB and Eisenman RN (2004) Myc: a weapon of mass destruction. Cell 117: 153-166

38. Sugimoto M, Kuo ML, Roussel MF and Sherr CJ (2003) Nucleolar Arf tumor suppressor inhibits ribosomal RNA processing. Mol. Cell 11: 415-424

39. Weber JD, Jeffers JR, Rehg JE, Randle DH, Lozano G, Roussel MF, Sherr CJ and Zambetti GP (2000) p53-independent functions of the p19(ARF) tumor suppressor. Genes Dev. 14: 2358-2365

40. Tsai KY, MacPherson D, Rubinson DA, Nikitin AY, Bronson R, Mercer KL, Crowley D and Jacks T (2002) ARF mutation accelerates pituitary tumor development in $\mathrm{Rb}^{+/-}$mice. Proc. Natl. Acad. Sci. USA 99: $16865-16870$

41. de Stanchina E, McCurrach ME, Zindy F, Shieh SY, Ferbeyre G, Samuelson AV, Prives C, Roussel MF, Sherr CJ and Lowe SW (1998) E1A signaling to p53 involves the p19(ARF) tumor suppressor. Genes Dev. 12: 2434-2442

42. Kamijo T, van de Kamp E, Chong MJ, Zindy F, Diehl JA, Sherr CJ and McKinnon PJ (1999) Loss of the ARF tumor suppressor reverses premature replicative arrest but not radiation hypersensitivity arising from disabled atm function. Cancer Res. 59: 2464-2469

43. Schmitt CA, Fridman JS, Yang M, Lee S, Baranov E, Hoffman RM and Lowe SW (2002) A senescence program controlled by p53 and p16INK4a contributes to the outcome of cancer therapy. Cell 109: 335-346

44. Dang J, Kuo ML, Eischen CM, Stepanova L, Sherr CJ and Roussel MF (2002) The RING domain of Mdm2 can inhibit cell proliferation. Cancer Res. 62: 12221230

45. Fridman JS, Hernando E, Hemann MT, de Stanchina E, Cordon-Cardo $C$ and Lowe SW (2003) Tumor promotion by Mdm2 splice variants unable to bind p53. Cancer Res. 63: 5703-5706

46. Bartel F, Taubert $\mathrm{H}$ and Harris LC (2002) Alternative and aberrant splicing of MDM2 mRNA in human cancer. Cancer Cell 2: 9-15

47. Perry ME, Mendrysa SM, Saucedo LJ, Tannous $P$ and Holubar M (2000) p76(MDM2) inhibits the ability of p90(MDM2) to destabilize p53. J. Biol. Chem. 275: $5733-5738$

48. Evan GI, Wyllie AH, Gilbert CS, Littlewood TD, Land H, Brooks M, Water CM, Penn LZ and Hancock DC (1992) Induction of apoptosis in fibroblasts by c-myc protein. Cell 69: 119-128
49. Ma D, Zhou P and Harbour JW (2003) Distinct mechanisms for regulating the tumor suppressor and antiapoptotic functions of Rb. J. Biol. Chem. 278: 1935819366

50. Santoni-Rugiu E, Falck J, Mailand N, Bartek J and Lukas J (2000) Involvement of Myc activity in a $\mathrm{G}(1) / \mathrm{S}$-promoting mechanism parallel to the $\mathrm{pRb} / \mathrm{E} 2 \mathrm{~F}$ pathway. Mol. Cell. Biol. 20: 3497-3509

51. Wymann D, Bluggel M, Kalbacher H, Blesken T, Akdis CA, Meyer HE and Blaser K (1999) Human B cells secrete migration inhibition factor (MIF) and present a naturally processed MIF peptide on HLA-DRB1*0405 by a FXXL motif. Immunology 96: 1-9

52. Abe R, Peng T, Sailors J, Bucala R and Metz CN (2001) Regulation of the CTL response by macrophage migration inhibitory factor. J. Immunol. 166: 747-753

53. Leng L, Metz CN, Fang Y, Xu J, Donnelly S, Baugh J, Delohery T, Chen Y, Mitchell RA and Bucala R (2003) MIF signal transduction initiated by binding to CD74. J. Exp. Med. 197: 1467-1476

54. Roger T, David J, Glauser MP and Calandra T (2001) MIF regulates innate immune responses through modulation of Toll-like receptor 4. Nature 414: 920-924

55. Leone G, Sears R, Huang E, Rempel R, Nuckolls F, Park CH, Giangrande P, Wu L, Saavedra HI, Field SJ, Thompson MA, Yang H, Fujiwara Y, Greenberg ME, Orkin S, Smith C and Nevins JR (2001) Myc requires distinct E2F activities to induce $S$ phase and apoptosis. Mol. Cell 8: 105-113

56. Santoni-Rugiu E, Duro D, Farkas T, Mathiasen IS, Jaattela M, Bartek J and Lukas J (2002) E2F activity is essential for survival of Myc-overexpressing human cancer cells. Oncogene 21: 6498-6509

57. Sherr CJ (2004) Principles of tumor suppression. Cell 116: 235-246

58. Cleveland JL and Sherr CJ (2004) Antagonism of Myc functions by Arf. Cancer Cell 4: 309-311

59. Trimarchi JM and Lees JA (2002) Sibling rivalry in the E2F family. Nat. Rev. Mol. Cell. Biol. 3: 11-20

60. DeGregori J (2002) The genetics of the E2F family of transcription factors: shared functions and unique roles. Biochim. Biophys. Acta. 1602: 131-150

61. Harbour JW and Dean DC (2000) The Rb/E2F pathway: expanding roles and emerging paradigms. Genes Dev. 14: 2393-2409

62. Zhang HS, Postigo AA and Dean DC (1999) Active transcriptional repression by the Rb-E2F complex mediates G1 arrest triggered by p16INK4a, TGFbeta, and contact inhibition. Cell 97: 53-61

63. Rounbehler RJ, Rogers PM, Conti CJ and Johnson DG (2002) Inactivation of E2f1 enhances tumorigenesis in a Myc transgenic model. Cancer Res. 62 : 3276-3281

64. Phillips AC, Ernst MK, Bates S, Rice N and Vousden KH (1999) E2F-1 potentiates cell death by blocking antiapoptotic signaling pathways. Mol. Cell 4 $771-781$

65. Hsieh JK, Fredersdorf S, Kouzarides T, Martin K and Lu X (1997) E2F1. induced apoptosis requires DNA binding but not transactivation and is inhibited by the retinoblastoma protein through direct interaction. Genes Dev. 11: 18401852

66. Phillips AC, Bates S, Ryan KM, Helin K and Vousden KH (1997) Induction of DNA synthesis and apoptosis are separable functions of E2F-1. Genes Dev. 11: $1853-1863$

Supplementary information accompanies the paper on Cell Death and Differentiation website (http://www.nature.com/cdd). 